\title{
PEMBERDAYAAN MASYARAKAT MELALUI PELATIHAN PEMBUATAN TANAMAN HIDROPONIK SEBAGAI UPAYA MEREALISASIKAN KAMPUNG HIJAU DI KELURAHAN KEBON PALA KOTA ADMINISTRASI JAKARTA TIMUR
}

\author{
Bambang Erwin', Riyadi Ismanto², \\ Rein Vikaris Panggalo ${ }^{3}$, Regina Tyas Awangsari Nastiti ${ }^{4}$ \\ Universitas Kristen Indonesia, Jakarta, Indonesia1234 \\ E-mail : berwin5753@yahoo.com;riyadi2282@yahoo.com;reinvikaris@gmail.com; \\ nastiti1504@gmail.com
}

\begin{abstract}
Abstrak
Green Action merupakan kegiatan Pengabdian pada Masyarakat Program Studi Arsitektur Fakultas Teknik Universitas Kristen Indonesia (FTUKI) yang melibatkan dosen, mahasiswa dan masyarakat. Kegiatan Green Action 22 yang diwujudkan dalam bentuk wujud nyata Pengabdian pada Masyarakat pada semester Gasal tahun akademik 2020/2021 mengambil tema tentang tanaman hidroponik yang dikemas dalam 2 kegiatan yaitu kegiatan Pelatihan membuat tanaman hidroponik dan dilanjutkan dengan kegiatan lomba. Dalam laporan kegiatan Pengabdian pada Masyarakat berisi tentang kegiatan Pelatihan membuat tanaman hidroponik sebagai strategi mewujudkan kampung hijau di RW 09 Kelurahan Kebon Pala Jakarta Timur. Pemilihan usaha tanaman hidroponik sangat tepat dilakukan oleh masyarakat perkotaan (kampung kota) yang banyak tinggal di lahan yang tidak luas, terbatas, namun dapat direncanakan kondisi yang ada untuk membuat tanaman hidroponik dan dapat dimanfaatkan minimal untuk kebutuhan keluarga. Keterbatasan lahan, kepadatan penduduk, kondisi tertentu misalnya masa pensiun, masa pandemic covid 19 seperti sekarang ini, membuat tanaman hidroponik merupakan pilihan yang paling tepat. Dengan waktu luang di rumah lebih banyak karena Work From Home (WFH) dapat mengisi waktu dengan berkegiatan menanam hidroponik, sebagai hiburan, menghilangkan stress, dan menghasilkan uang. Metode yang dilakukan adalah mengadakan Pelatihan Pembuatan Tanaman Hidroponik dengan narasumber pakar Hidroponik, yang diikuti oleh 5 RT di RW 9 sebagai peserta. Hasil rapat koordinasi dengan aparat pemerintahan tingkat kelurahan dan RW, wakil RT setempat, ditentukan hanya 5 RT masing-masing RT diwakili 1-2 peserta. Metoda pelatihan mengingat harus menjaga Protokol Kesehatan secara ketat, semua kegiatan dilaksanakan secara online/daring.
\end{abstract}

Kata Kunci : Green Action, Pelatihan Hidroponik, Kampung Hijau

\begin{abstract}
Green Action is a Community Service activity in the Architecture Study Program, Faculty of Engineering, Indonesian Christian University (FTUKI) which involves lecturers, students and the community. The Green Action 22 activity which was realized in the form of a tangible form of Community Service in the Odd semester of the 2020/2021 academic year took the theme of hydroponic plants which was packaged in 2 activities, namely Training activities to make hydroponic plants and followed by competition activities. In this Community Service activity report, the author reports on training activities to make hydroponic plants as a strategy to realize a green village in RW 09, Kebon Pala Village, East Jakarta. The selection of a hydroponic plant business is very appropriate for urban communities (urban villages) who live in large, limited land, but the existing conditions can be planned to make hydroponic plants and can be utilized at a minimum for family needs. Limited land, population density, certain conditions such as retirement, during the COVID-19 pandemic as it is today, making hydroponic plants the most appropriate choice. With more free time at home because Work From Home (WFH) can fill time with hydroponic planting activities, as entertainment, relieve stress, and make money. The method used is holding a Hydroponic Plant Making Training
\end{abstract}


with hydroponic expert resource persons, which was attended by 5 RTs in RW 9 as participants. The results of the coordination meeting with government officials at the kelurahan and RW levels, representatives of local RTs, it was determined that only 5 RTs each represented 1-2 participants. The training method remembers having to strictly maintain the Health Protocol, all activities are carried out online.

\section{Key words : Green action, hydroponic, Green village of Kebon Pala}

\section{PENDAHULUAN}

Progam studi S1 Arsitektur Fakultas Teknik UKI (FTUKI) pada semester gasal 2020/2021 melakukan kegiatan

Pengabdian pada masyarakat, bekerja sama dengan RW 09 Kelurahan Kebon Pala Jakarta Timur. Kegiatan ini merupakan kegiatan yang berlanjut dari tahun sebelumnya, yang sudah terjalin kerjasama antar institusi antara Kelurahan Kebon Pala dengan Prodi Arsitektur FTUKI. Tujuan dari kegiatan Pengabdian pada Masyarakat di RW 09 adalah keikutsertaan Program Studi Arsitektur FTUKI dalam kegiatan Pembinaan Kampung hijau di kelurahan Kebon Pala Jakarta Timur.

Program Studi Arsitektur FTUKI berupaya untuk mewujudkan visi misinya salah satu nya dengan melakukan Pengabdian Pada Masyarakat dalam kegiatan Green Action 22 yaitu pemberdayaan masyarakat melalui Pelatihan Pembuatan Tanaman Hidroponik sebagai upaya merealisasikan kampung hijau di Kelurahan Kebon Pala Kota Administrasi Jakarta Timur. Kelurahan Kebon Pala adalah sebuah kelurahan di Kecamatan Makasar, Jakarta Timur, kelurahan ini memiliki penduduk sebesar 37.226 jiwa (desember 2008) dan luas wilayah 2, $29 \mathrm{~km} 2$. Kelurahan ini berbatasan dengan Kelurahan Cipinang Besar Selatan di sebelah utara, Kelurahan Halim Perdanakusuma dan Kelurahan Makasar di sebelah selatan, sebelah timur berbatasan dengan kelurahan Cipinang Melayu dan kelurahan Halim Perdanakusuma, di sebelah barat dengan kelurahan Cililitan dan kelurahan Cawang (wikipedia.org).

Program Green Action merupakan Program Pengabdian pada Masyarakat yang mulai dilaksanakan oleh Program Studi Arsitektur FTUKI sejak bulan Mei 2009 dalam program penghijauan, lomba kampung hijau dan penyuluhan di Kelurahan Cawang, Jakarta Timur. Kemudian kegiatan Green Action Program Studi Arsitektur FTUKI memperluas kawasan untuk pengabdian pda masyarakat di kelurahan Kebon Pala Jakarta Timur. Program Green Action ini memiliki tujuan pemberdayaan masyarakat melalui pelatihan pembuatan tanaman hidroponik sebagai upaya merealisasikan Kampung Hijau di Kelurahan Kebon Pala Kota Administrasi Jakarta Timur.

Di era Pandemi covid 19 ini, masyarakat RW 09 Kelurahan Kebon Pala Kota Administrasi Jakarta Timur lebih banyak 
bekerja dirumah sehingga aktivitas pun berkurang. Sehingga diharapkan di era new normal ini warga di Kelurahan Kebon Pala mulai berkegiatan atau beraktivitas salah satunya dengan membuat tanaman hidroponik yang diharapkan dapat menggiatkan kembali kegiatan yang pernah ada di era sebelum covid 19.

Kegiatan Pengabdian Pada Masyarakat Program Studi Arsitektur FTUKI dalam Green Action 22, terdiri dari rangkaian acara diantaranya Pelatihan pembuatan tanaman hidroponik yang diikuti oleh warga RW 09. Materi disampaikan oleh narasumber yang berkompeten di bidang tanaman hidroponik dan dibantu oleh mahasiswa program studi Arsitektur FTUKI kepada masyarakat di RW 09 Kelurahan Kebon Pala Jakarta Timur. Sedangkan peserta pelatihan terdiri dari pihak Kelurahan, Ketua RW, Karang Taruna, seluruh Ketua RT, PKK, dan peserta lomba hidroponik yang diikuti oleh 6 RT.

Kegiatan Pengabdian Pada Masyarakat ini diharapkan mampu mengedukasi masyarakat mengenai tanaman hydroponik dan membangkitkan semangat masyarakat dalam mewujudkan kampung hijau yaitu dengan berkreasi dengan tanaman hidroponik

\section{METODE PELAKSANAAN}

Metode yang dipakai pada program pemberdayaan masyarakat melalui pelatihan pembuatan tanaman hidroponik sebagai upaya merealisasikan kampung hijau di Kelurahan Kebon Pala Jakarta Timur, adalah sebagai berikut :

1. Menentukan lokasi kegiatan di Kelurahan Kebon Pala Jakarta Timur, dengan memilih RW 09, dengan pertimbangan sudah terjalin kerjasama antar Prodi Arsitektur FTUKI dengan RW 09 Kelurahan Kebon Pala.

2. Menentukan peserta lomba dengan mengadakan rapat koordinasi secara online antara tim Pengabdian pada Masyarakat Prodi Arsitektur FTUKI dengan Ketua RW dan perwakilan RT di RW 09, ditentukan 6 RT sebagai peserta lomba, yaitu RT 04 (1 peserta), RT 07 (1 peserta), RT 08 (1 peserta), RT 09 (2 peserta) dan RT 12 (1 peserta).

3. Peserta lomba, selanjutnya dilakukan pelatihan atau workshop tentang cara membuat tanaman hidroponik di rumah masing-masing peserta, yang nantinya hasil pelatihan akan dipraktekkan dalam lomba tanaman hidroponik antar peserta pelatihan.

4. Sebelum dilakukan pelatihan dan workshop, peserta lomba diberikan oleh Prodi Arsitektur FTUKI 1(satu) set peralatan yang akan dipakai sebagai peralatan praktik pada saat pelatihan dan selanjutnya untuk media lomba.

\section{HASIL DAN PEMBAHASAN}

Kegiatan Pengabdian Pada Masyarakat di RW 09 Kelurahan Kebon Pala Jakarta Timur, terdiri dari dua kegiatan, yaitu kegiatan sosialisasi dan pelatihan 
pembuatan tanaman hidroponik dan kegiatan lomba tanaman hidroponik. Kegiatan pelatihan dan workshop Lomba Kreativitas Tanaman Hidroponik ini diikuti oleh enam (6) kelompok dimana masingmasing kelompok terdiri dari satu (1) orang yang berasal dari RW 09. Dari materi pelatihan dari nara sumber Bapak Ir Ronny Tanumiharja dapat di sampaikan rangkuman sebagai bahan panduan bagi para peserta lomba.

\section{A. Bertanam sayuran hidroponik salah} satu pilihan kegiatan yang tepat.

Bertanam sayur hidroponik merupakan pilihan yang tepat bagi warga perkotaan, yang mengalami masa pension banyak waktu luang sehingga pilihan kegiatan ini merupakan pilihan yang tepat. Demikian pula bagi warga di perkotaan yang memiliki lahan yang kecil, terbatas untuk bercocok tanam, sehingga hidroponik merupakan pilihan yang tepat. Disamping itu ada beberapa alasan bertanam sayuran secara hidroponik sebagai kegiatan yang menjanjikan, karena :

1. Sangat mudah dilaksanakan

2. Bisa dilakukan oleh siapa saja

3. Swa sembada pangan

4. Tidak menyita banyak waktu dan tenaga

5. Biaya/modal awal kecil

6. Tidak memerlukan lahan khusus

7. Pertumbuhan penduduk makin cepat
8. Produk yang dihasilkan bermanfaat dan mudah/laku dipasarkan

9. Mendatangkan kepuasan / kegembiraan, sehingga menjadi hobby yang menyenangkan.

Kelebihan bertanam hidropnik, adalah

1. Mudah dilakukan, murah dan menyenangkan

2. Hemat lahan

3. Hemat penggunaan air dan pupuk

4. Dapat menanam di lahan yang sempit, di roof top.

5. Dapat menghilangkan stress.

Karena tanaman hidroponik unsur utamanya adalah air maka yang harus diperhatikan pada saat membuat tanaman hidroponik adalah :

1. Kualitas air harus bagus, bersih.

2. Kualitas benih, pemilihan bibit atau benih yang baik dan cocok untuk tanaman hidroponik

3. Bahan yang dipakai

4. Sistem yang digunakan

5. Jenis tanaman

6. Kondisi lingkungan

\section{B. Tahapan Bertanam Hidroponik}

Proses menanam hidroponik melalui beberapa tahapan yaitu :

1. Penyemaian (pembititan)

2. Pemindahan Bibit Tanaman

3. Pemeliharaan / perawatan

Sejak bibit ditempatkan pada modul tanam, yang perlu dilakukan hanyalah:

a. Memastikan volume air di dalam bak yang dipompakan cukup (tidak boleh di bawah permukaan pompa) 
b. Check kadar kandungan nutrisi (ppm) dan menambahkan nutrisi secukupnya sesuai usia tanaman

4. Panen

Misalnya masa panen :

- Daun Kale [35-50 hari

- Bayam hijau [30-45 hari]

- Bayam merah [40-50 hari]

- Daun bawang [60-75 hari]

- Pakcoy [45-50 hari]

\section{Bahan-bahan \& Peralatan}

1. Bahan/penyemaian/Pembibitan:

a. Bibit sayuran yang akan ditanam

b. Media tanam :

1) Rock woll

2) Karet busa / sponge

3) Clay ball

4) Sekam bakar

5) Cocopeat

6) Tissue

c. Pisau bergerigi/gergaji besi kecil (utk memotong-motong rockwool)

d. Nampan plastik \& air bersih (utk membasahi rockwoll)

e. Mangkok kecil \& Tusuk gigi untuk memasukkan butiran benih ke rockwool

\section{Bahan / Peralatan Modul Tanam} (tempat penanaman sayuran) :

a. Pipa PVC diameter 3 inci dilobangi (diameter lobang $4.5 \mathrm{~cm}$, jarak antar lobang $15 \mathrm{~cm}$ ), yang biasa disebut Modul. b. Netpot (= gelasplastik kecil berlobang2 utk menempatkan rockwool di pipa/air)

c. Potongan kain flannel (jika dasar gelas tidak menyentuh permukaan air di pipa)

d. Bak plastik penampung air, pompa \& rangkaian pipa utk mengalirkan nutrisi

\section{Bahan/Peralatan selama Masa}

\section{Pertumbuhan / Perawatan:}

1) Nutrisi (Pupuk) - Paket Nutrisi $A$ dan B (dicampur 50\%-50\%)

Pupuk / nutrisi hidroponik merupakan ramuan pupuk yang berupa minera I / garam garaman yang berfungsi untuk memenuhi

kebutuhan nutrisi/hara bagi tanaman.

Ramuan ini terbagi 2 yaitu :

a) Ramuan $A$ yang terdiri dari kalsium nitrat, kalium nitrat dan Fe EDTA yang berfungsi untuk memenuhi kebutuhan hara makro bagi tanaman.

b) Ramuan B yang terdiri dari kalium dihidro fosfat, amonium sulfat, kalium sulfat, magnesium sulfat, cupri sulfat, zinc sulfat, asam borat, mangan sulfat dan amonium hepta molibdat yang berfungsi untuk memenuhi kebutuhan hara/mikro bagi tanaman. 
2). Dua buah Jiregen kapasitas 5 Itr (tempat larutan nutrisi) \& Plastik/Gelas Ukur

1) TDS meter (utk mengukur kandungan nutrisi)

2) $\mathrm{pH}$ meter (diperlukan utk mengukur $\mathrm{pH} / \mathrm{kwalitas}$ air yang digunakan)

a) Sejak bibit ditempatkan pada modul tanam, yang perlu dilakukan hanyalah: memastikan volume air di dalam bak yang dipompakan cukup, tidak boleh di bawah permukaan pompa

b) Check kadar kandungan nutrisi dan menambahkan nutrisi secukupnya sesuai usia tanaman

\section{Bahan/Peralatan}

\section{Penyemaian/Pembibitan:}

1. Rock woll

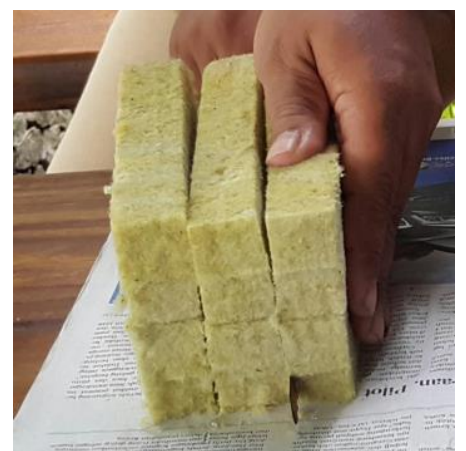

\section{Gambar 1 : Rockwoll}

- Rockwoll merupakan bahan yang terbaik untuk menyemai.

- Ramah lingkungan

- Hanya bisa dipakai sekali saja.
2. Karet busa / sponge

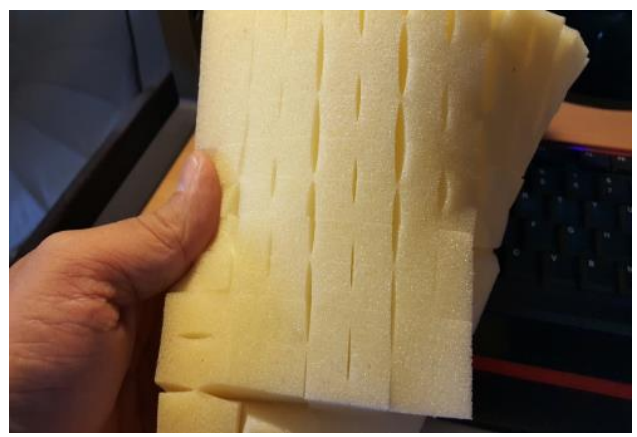

Gambar 2 : Karet busa/sponge

- Karet busa bisa juga dipakai untuk media tanam

- tetapi karena sifatnya yang tidak bias menyimpan air

- kalau dipakai sebagai media harus selalu terendam air.

3. Clay ball / hidroton

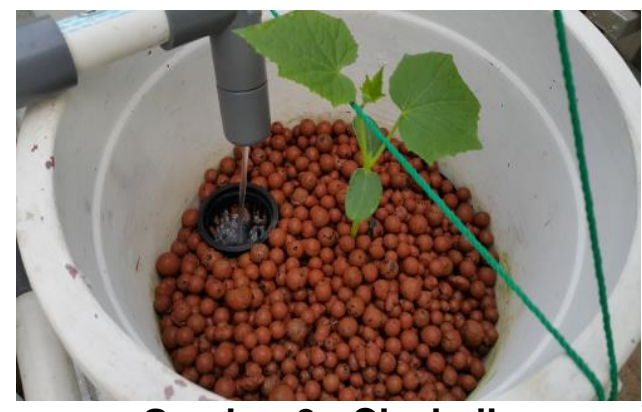

Gambar 3 : Clayball

- Media tanam clay ball sangat baik untuk tanaman buah

4. Sekam bakar

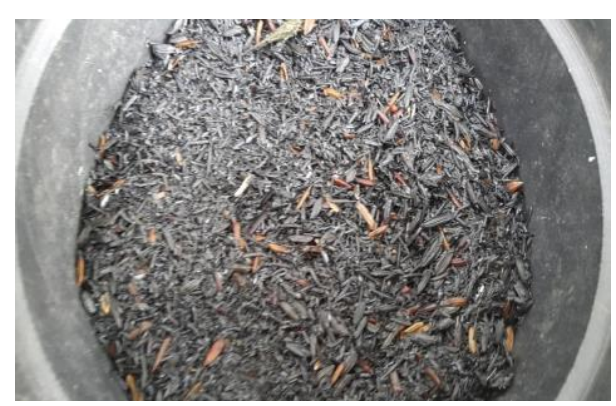

Gambar 4 : Sekam bakar 
- Bahan bakunya mudah didapat/membuatnya

- tidak dapat menyimpan air

\section{Cocopeat}

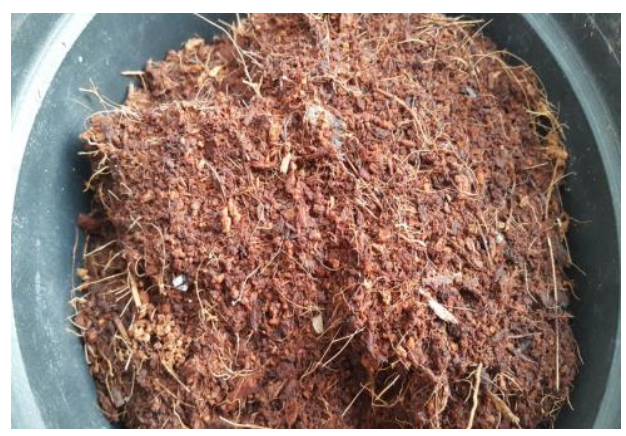

Gambar 5 : Cocopeat

\section{E. Bahan/Peralatan}

\section{Penyemaian/Pembibitan:}

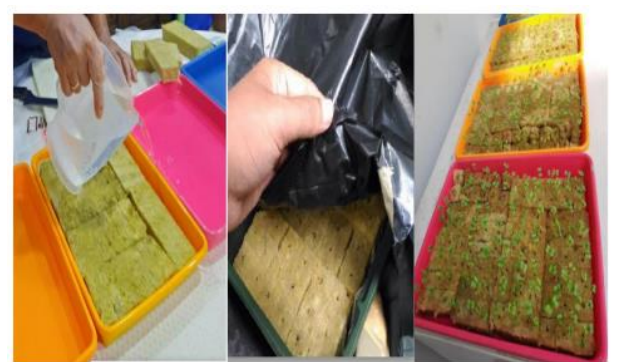

Gambar 6 : Menyemai benih sayuran ke dalam rock woll

\section{Peralatan penunjang untuk menyemai}

1. Netpot (= gelas plastik kecil berlobang2 utk menempatkan rockwool di pipa/air)

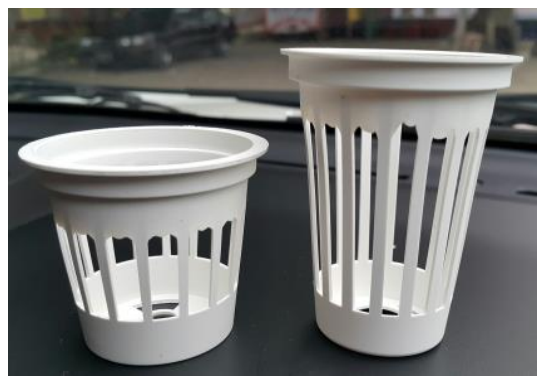

Gambar 7 : Netpot
Net pot, tanaman hidroponik tempat sumbu Flanel, rock woll dan biji tanaman Net pot dengan sumbu dan tanaman Kain flannel dipakai sebagai sumbu air

2. TDS meter (untuk mengukur kandungan nutrisi)

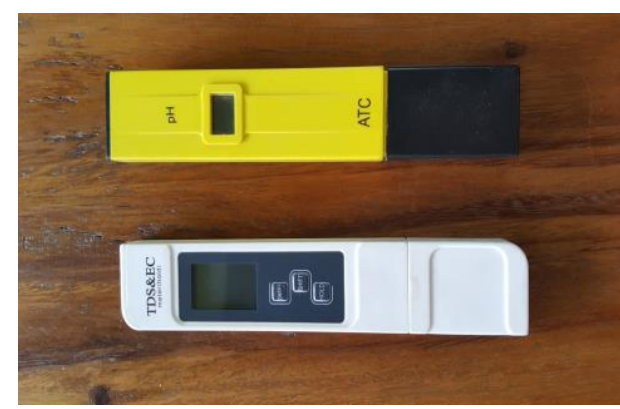

Gambar 8 : TDS meter

3. Modul Tanam (Rangkaian Pipa PVC 3")

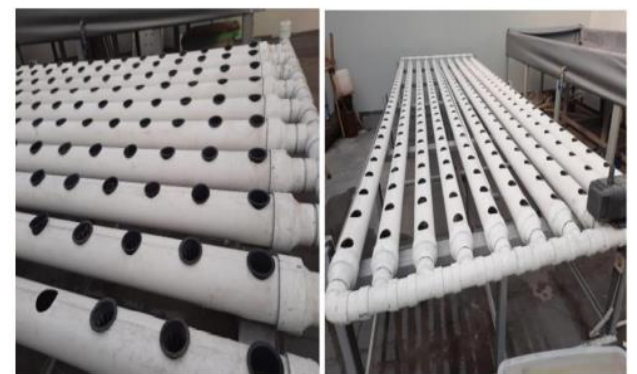

Gambar 9 : Modul tanam

\section{F. Sistem dalam hidroponik}

Pembuatan tanaman hidroponik dapat dilakukan dakam beberapa cara, yaitu :

1. Menggunakan air a. Sistem wick atau sumbu 


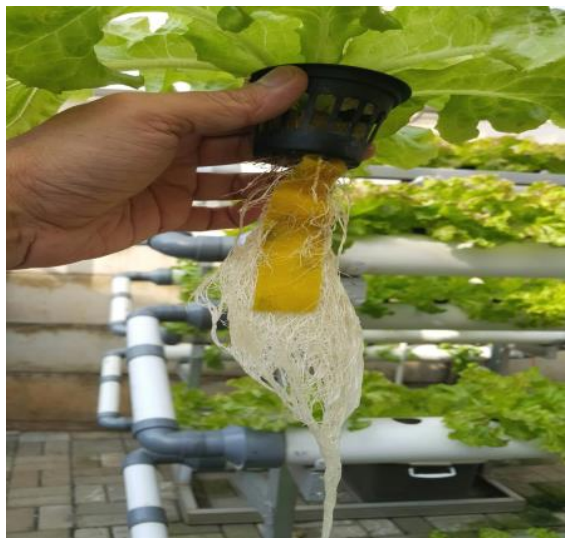

Gambar 10 : Sistem sumbu

Sistem Wick atau sumbu hanya menggunakan netpot dan sumbu sebagai penyambung akar sampai masuk kedalam genangan air nutrisi.

\section{b. Sistem Rakit Apung}

Sistem rakit apung biasanya digunakan untuk skala bisnis, dengan kapasitas yang lebih besar, tahan terhadap panas

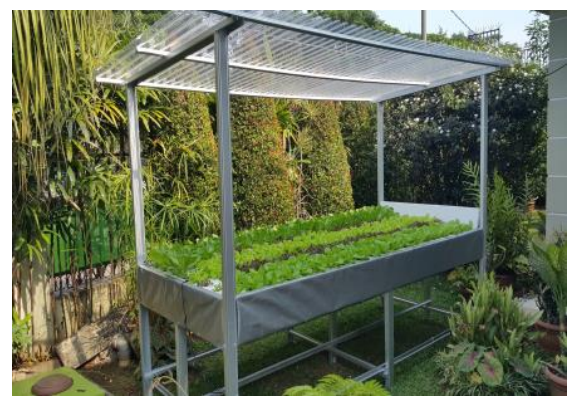

\section{Gambar 11 : Sistem rakit apung}

Rakit Apung, dengan membuat bak air dari rangka aluminium hollow dan kain terpal. Tanaman hidroponik diletakkan di atasnya dengan media stereofoam dan netpot.

\section{c. Sistem NFT (Nutrient Film Technique)}

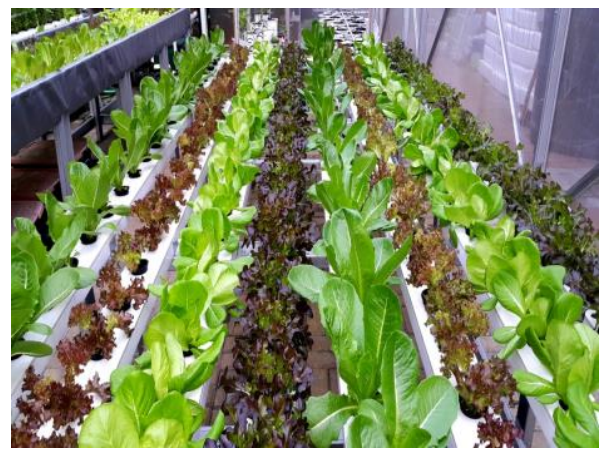

Gambar 12 : Sistem NFT

- Prinsipnya mengairi akar tanaman dengan larutan nutrisi

- Menggunakan wadah seperti gully yang berbentuk seperti pipa

- Menggunakan pompa untuk sirkulasi air nutrisi

- Cocok untuk menanam sayursayuran

\section{d. Sistem DFT (Deep Flow Techniq)}

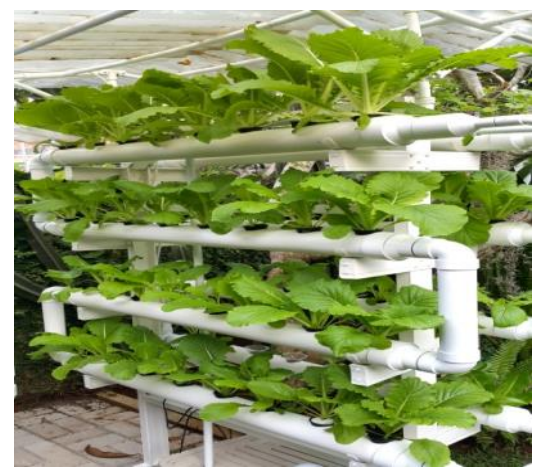

\section{Gambar 13 : Sistem DFT}

- Prinsipnya mengairi akar tanaman dengan larutan nutrisi

- Menggunakan wadah seperti gully yang berbentuk seperti pipa 
- Menggunakan pompa untuk sirkulasi air nutrisi

- Menggunakan modul pipa berlobang lobang

\section{Menggunakan substrat}

\section{a. Sistem Drip/tetes}

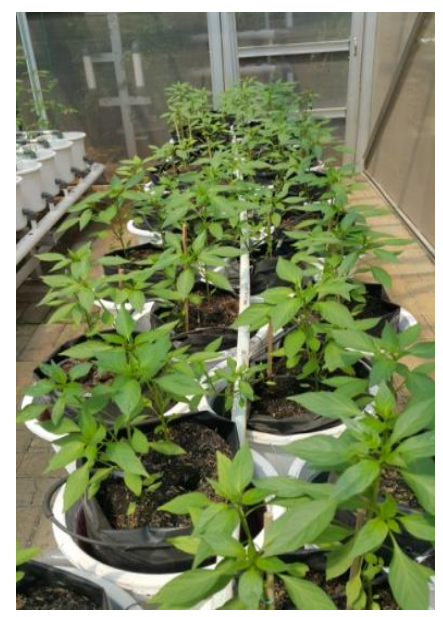

Gambar 14 : Sistem Drip

- Memberikan larutan nutrisi dalam bentuk tetesan

- Menggunakan selang dan drip stick

- Menggunakan pompa untuk mengalirkan air dan larutan air nutrisi

- Menggunakan sekam bakar, dan cocopeat atau media lain sebagai media tanamnya.

- Jadwal dan porsi tetesannya diatur oleh timer

\section{Sistem Dutch Bucket}

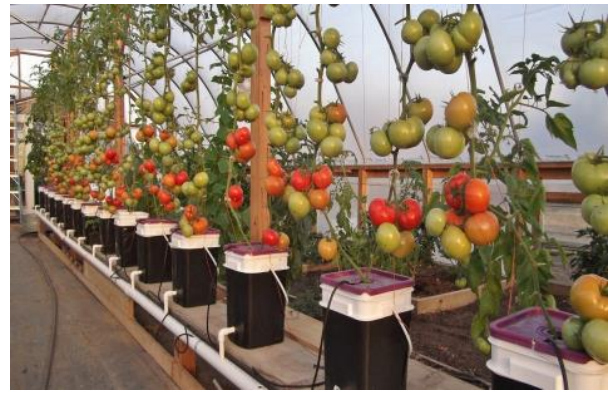

\section{Gambar 15 : Sistem Dutch Bucket}

- Memberikan larutan nutrisi ke akar tanaman dalam bentuk aliran

- Menggunakan pipa PVC diameter besar dan kecil

- Menggunakan pompa untuk mendorong dan mengalirkan larutan nutrisi secara sirkulasi

- Memakai clay ball sebagai media tanamnya

- Cocok untuk menanam buahbuahan.

\section{SIMPULAN}

Para peserta dapat mengkuti pelatihan dengan jelas, mengerti, memahami dan mempraktekkan hasil teori ke dalam lomba tanaman hidroponik, melalui peralatan yang sudah diberikan oleh Program Studi Arsitektur FTUKI. Pelatihan ini diharapkan sebagai pembelajaran membuat tanaman hidroponik yang dimulai dari skala kecil. Diharapkan peserta sebagai wakil masingmasing RT mampu membuat tanaman hidroponik yang dipanen untuk kepentingan pribadi, dan menularkan ilmu hidroponik kepada semua warga di RW 09 Kelurahan Kebon Pala Jakarta Timur. 
7. Warga RW 09 di Kelurahan Kebon

UCAPAN TERIMAKASIH

Puji dan syukur penulis panjatkan ke hadirat Tuhan Yang Maha Esa, karena berkat rahmat dan karunia-Nya penulis dapat menyelesaikan seluruh proses penyusunan Laporan Program Pengabdian Pada Masyarakat Program Studi Arsitektur Fakultas Teknik UKI yang berjudul Green Action 22 Pemberdayaan Masyarakat melalui Pelatihan Tanaman Hidroponik sebagai Strategi dalam Mewujudkan Kampung Hijau di RW 09 Kelurahan Kebon Pala Kota Administrasi Jakarta Timur.

Penulis mengucapkan banyak terima kasih kepada :

1. Bapak Dr. Dhaniswara K. Harjono, SH., MH., MBA, sebagai Rektor Universitas Kristen Indonesia.

2. Ibu Ir.Galuh Widati, M.Sc, sebagai Dekan FTUKI.

3. Bapak Ir.Sahala Simatupang, MT, sebagai Ketua Program Studi Arsitektur FTUKI.

4. Bapak Lurah Kelurahan Kebon Pala Kota Jakarta Timur 2020 yaitu Bapak Ir.Faisal Rizal, M.Kes

5. Tim Pelaksana Pengabdian pada Masyarakat : Ulinata, ST.Ars., MT, Ir.Bambang Erwin, MT, Ir. Riyadi Ismanto, M.Arch, Grace Putri Dianty, ST., M.Ars.

6. Mahasiswa yang ikut serta yaitu Ajeng Evita Dewi Hasugian, Enrique Keenan Kidingallo, Rein Vikaris Panggalo, Regina Tyas Awangsari Nastiti
Pala, Kota Administrasi Jakarta Timur khususnya Para Peserta Lomba yang sudah meluangkan waktu dan tenaganya untuk mengikuti pelatihan pembuatan tanaman hidroponik sebagai strategi dalam mewujudkan

Kampung Hijau di RW 09 Kelurahan Kebon Pala Kota Administrasi Jakarta Timur.

8. Bapak Rohedi yang telah berkenan untuk membantu koordinasi kepada Kelurahan dan para peserta.

9. CatalogPro yang meliput dan mempublish ke media online CatalogPro dalam kegiatan Program Pengabdian Pada Masyarakat Program Studi Arsitektur FTUKI yang berjudul Green Action 22 Pemberdayaan masyarakat melalui Pelatihan Pembuatan Tanaman Hidroponik sebagai Strategi dalam mewujudkan kampung hijau di RW 09 Kelurahan Kebon Pala Kota Administrasi Jakarta Timur

10. Semua pihak yang berpartisipasi untuk mensukseskan Program Pengabdian Pada Masyarakat ini. Semoga laporan hasil kegiatan bermanfaat bagi kita semua khususnya di lingkungan Program Studi Arsitektur FTUKI. 


\section{REFERENSI}

Halim, Jimny (2016) " 6 Teknik Hidroponik, Penebar Swadaya Grup.

Lingga, Pinus (1984): " Hidroponik tanpa tanah “, Niaga Swadaya Press.

Sugeng, Heru (2020) : “ Mencari kesibukan dan mendapat tambahan penghasilan dengan bertanam sayur hidroponik di rumah" Jakarta

Sutanto, Teguh (2015) : " Rahasia Sukses Budidaya Tanaman dengan metode Hidroponik “ , Bibit Publisher

Tanumiharja, Ronny (2020) : “ Materi Pelatihan : Bertani cerdas ala hidroponik sebagai salah satu pilihan pengembangan usaha, Jakarta 2020 